This review essay critically examines Hannah Strømmen and Ulrich Schmiedel's The Claim to Christianity, an activist intervention that seeks to explicate and contest the theologies running through far-right claims to Christianity. While importantly focused on the semantic struggle for Christianity, refusing to interpret the presence of Christianity in far-right ideology as mere instrumentalisation, and espousing a critical Christianity without guarantees, the book suffers from several analytical and evaluative shortcomings. Framing the object of Strømmen and Schmiedel's work as a component part of the contemporary post-fascist atmosphere, I suggest that drawing on the work of Ernst Bloch and Antonio Gramsci and attending to the utopian, dystopian, stratified, temporally multiple, and synthetic qualities of far-right claims to Christianity better illuminates the ideological operations of post-fascism and suggests the need for powerful alternative theologies. 
Review essay

\section{Christianity Without Guarantees}

\section{CHAMSY EL-OJEILI}

Machiavelli's Prince could be studied as an historical exemplification of the Sorelian 'myth' - i.e. of a political ideology expressed neither in the form of a cold utopia nor as learned theorizing, but rather by a creation of concrete phantasy which acts on a dispersed and shattered people to arouse and organise its collective will. ${ }^{1}$

I want to begin with five snapshots from the last couple of years that provide entry points into the puzzling, heterogeneous connections between today's far right and Christianity, the topic of Hannah Strømmen and Ulrich Schmiedel's The Claim to Christianity. In March 2019, the perpetrator of the Christchurch attacks acknowledged the influence of Anders Behring Breivik and the latter's fantasy role as 'a strong and just knight of Christianity.' Later that month, manosphere pick-up artist V Roosh (Daryush Valizadeh) announced he had taken the 'God pill' and become a Christian, unpublishing certain of his writings (largely devoted to how to 'bang' women), but continuing, nevertheless, to espouse modified alt-right themes, contending that America was 'a clown country where we

1 Antonio Gramsci, Selections from the Prison Notebooks (London: Lawrence and Wishart, 1998), 123-124.

2 Breivik in Hannah Strømmen and Ulrich Schmiedel, The Claim to Christianity: Responding to the Far Right (London: SCM Press, 2020), 44. 
suffer daily humiliations and degradations at the hands of sodomites, manjawed feminists, cuckolds and aliens'. ${ }^{3}$ In August of the same year, Lega's Matteo Salvini, sporting a prominent crucifix, partied on an Italian beach, posing for fan selfies, drinking mojitos, and ogling women. The following June, Donald Trump had BLM protestors dispelled with tear gas and flash-bang grenades to make a theatrical walk from the White House to St John's Episcopal Church, where he posed for photos with a backwards and upside-down Bible held aloft, having previously appeared, in a televised interview with Bloomberg's John Heilemann and Mark Halperin, unable to name his favourite chapter in this, his 'favourite book of all time'. ${ }^{4}$ And in July 2021, Steve Bannon's sovereignist school for 'gladiators of populism and nationalism', an 'academy for the Judeo-Christian West', situated in a former monastery outside Rome that has been entrusted to the far-right Catholic think tank Dignitatus Humanae Institute, is scheduled to accept its first intake of students.

Seeking to make sense of this kind of material, Strømmen and Schmiedel's recent work is an activist intervention by and for Christian leftists, in which the authors attempt to explicate the theologies running through far-right claims to Christianity, and to intervene, reclaiming Christianity from this right. As a number of commentators have noted, the far right has recently attempted to frame its politics in more explicitly religious terms. George Hawley has suggested that while a good chunk of the US alt-right has been critical of Christianity-following the lines of Nietzsche's The Anti-Christ, opting for Greco-Roman or Norse religious affiliations, or vigorously opposing the centrism of the mainstream Christian right-a more accommodating stance has recently become visible. ${ }^{5}$ Similarly, Liz Fekete has noted the increasing centrality of Christian identity themes to the far right, who seek to frame themselves as 'protectors

3 Roosh in Tara Isabella Burton, 'A notorious pickup artist found God. Lots of angry white radicals do,' Washington Post, 31 May 2019.

4 In Luke O'Neil, 'What do We Know About Trump's Love for the Bible?' The Guardian, 2 June 2020.

5 George Hawley, Making Sense of the Alt-Right (New York: Columbia University Press, 2017). 
of religion', of family, of heterosexual norms. ${ }^{6}$ In like fashion, Jose Pedro Zuquete has argued that we are seeing a Christian revival among European identitarians, while Rogers Brubaker has contended that we can detect a widespread populist shift from nationalism to 'civilizationism', which includes, crucially, the growing salience of Christian identity, or what he calls 'Christianism'?

More generally, the 'return to religion', or a 'post-secular' cultural shift, has been a major theme of commentary on the contemporary period. Very often, this return or shift is viewed as a response and contributing factor to crisis. Variously, religious reidentification is seen to be shaped by dislocating and threatening social change; by a quest for identity, belonging, and community in unstable, disorienting, or menacing circumstances; by a cognitive mapping exercise that seeks to tame an increasingly fragmented and illegible world; and by being a factor in rising polarisation and intercommunal tension and violence. Within this literature, today's religious turn is often framed as an issue concerning existential and identity questions but, equally, as a thoroughly political phenomenon: as ideological (about the intertwining of power and knowledge) and utopian (about the search for a better way of being).

A number of recent Gramscian analyses suggest that ours is a period of hegemonic or 'organic' crisis, akin to the interregnum of the 1930s, in which the dominant liberal order is crumbling. This is evidenced by growing multipolarity and the contestation of US power, declining commitments to traditional political parties, financial crises, austerity, rising inequality,

6 Liz Fekete, 'White Supremacy, Racial Patriarchy: Two Sides of the Same Coin,' Verso Blog, 27 August 2019.

7 Jose Pedro Zuquete, The Identitarians: The Movement Against Globalism and Islam in Europe (University of Notre Dame Press: Notre Dame, 2018); Rogers Brubaker, 'A New Christianist Secularism in Europe,' The Immanent Frame, 11 October 2016; 'Between Nationalism and Civilizationism: The European Populist Movement in Comparative Perspective,' Ethical and Racial Studies 40, no. 8 (2017): 1191-1226. With 'civilizationism', Brubaker is drawing on Samuel Huntington's notorious understanding of a civilization as 'a cultural entity, the highest grouping of people at the broad level of cultural identity', and of the world as split into eight major civilizations (Western, Confucian, Islamic, and so on): Samuel Huntington, 'The Clash of Civilizations,' Foreign Affairs 72 (1993): 22-49. 
the reduced effectiveness of key institutions, and the erosion of 'common civic identity'. ${ }^{8}$ Amidst all this, we see popular detachment from prevailing ideologies, political elites increasingly unable to provide moral and intellectual leadership, and the emergence of new lines of confrontation and competing projects. In Owen Worth's framing, three major attempts to forge a new popular prince (the formation of a 'civil bond' between leaders and the people) have come into view: one from the left, in progressive internationalism; one from a right-nationalist direction, which challenges globalisation, multiculturalism, and immigration; and one from above: God as mobilising passion.?

The chosen terrain of The Claim to Christianity - the semantic struggle for Christianity, and the authors' efforts to think through the ways in which 'the cogs' of far-right theologies 'hang together'-has clear Gramscian affinities. ${ }^{10}$ In compelling fashion, Strømmen and Schmiedel reject liberalChristian attempts to underscore the merely cynical, manipulative, and shallow appropriation and misuse of Christian themes and symbols by the far right; they favour instead a more critical Christianity, a Christianity without guarantees, which acknowledges the contradictions, mixed history, and multiple lineages and forms of Christianity. Nevertheless, in the book's over-riding activist focus, centred on Christianity as a practical project or way of 'doing', a number of central analytical and evaluative shortcomings are apparent. Here, a more nuanced interpretative approach, attendant to questions of utopia, dystopia, power, cognitive mapping, masculinity, backlash politics, and the way various exigencies are 'knotted together', helps us to better understand the far-right claim to Christianity as a response to current intellectual and moral disorganisation, as an attempt at arousing

8 See Milan Babic, 'Let's Talk About the Interregnum: Gramsci and the Crisis of the Liberal World Order,' International Affairs 96, no. 3 (2020): 767-786; Rune Møller Stahl, 'Ruling the Interregnum: Politics and Ideology in Nonhegemonic Times,' Politics and Society 47, no. 3 (2019): 333-360.

9 Owen Worth, Resistance in the Age of Austerity: Nationalism, the Failure of the Left and the Return of God (New York: Zed Books, 2013); Morbid Symptoms: The Global Rise of the Far-Right (Devon: Zed Books, 2019).

10 Strømmen and Schmiedel, The Claim to Christianity, 9. 
and organising collective will by way of a mythic 'concrete phantasy'; in this case, a mythic Christian form of 'total social practice' which needs to be opposed by a more powerful alternative theology than that suggested by Strømmen and Schmiedel. ${ }^{11}$

\section{The objects of analysis}

Strømmen and Schmiedel's work seeks to analyse and interpret the theologies running through contemporary far-right claims to Christianity. Focusing on Europe, Strømmen and Schmiedel examine three major moments of this Christianity-far right connection, in substantive chapters devoted to the 'terrorist right' (Breivik in Norway), the 'populist right' (PEGIDA and AfD in Germany), and the 'hard right' (the BNP and UKIP in England), although they leave their reasons for these conceptual distinctions unexplained. While there are clear differences between, say, Breivik's and UKIP's appeals to Christianity, Strømmen and Schmiedel insist on the crucial ideological connections in play between these moments. Principally, they are connected by a shared essentialism and a related Islamophobia. This essentialism views identities, cultures, and civilisations as sealed, unchanging, without movement, contradiction, and internal variation. Such an essentialist view is expressive of a new racism, which moves from a now widely discredited biological essentialism of racial types to an emphasis on basic and insuperable cultural and religious differences. Here, Islam is characterised as totalitarian and expansionist and immune from Western values such as democracy, human rights, toleration of plural lifestyles, and the rule of law. Across all three moments, this ahistorical and static essentialism and its accompanying stereotypes and general claims are evident in what Strømmen and Schmiedel call a 'Culture Christianity'. This

11 Respectively: Gramsci, Selections from the Prison Notebooks, 241, 124; Fabio Frosini in Cosimo Zene, 'Subalterns in the World: Typologies and Nexus with Different Forms of Religious Experience,' in Gramsci in the World, eds. Fredric Jameson and Roberto Dainotto (Durham: Duke University Press, 2020), 122; Ernst Bloch, The Heritage of Our Times (Cambridge: Polity, 1991). 
entails defending Europe's Christian heritage and essence against Islamisation, and often against a multiculturalist tolerance that aids such Islamisation. Additionally, in the terrorist right, we see a 'Crusader Christianity', which is shaped by a more violent and backward-looking imaginary and takes a more militaristic line on the need for aggressive self-defence.

In the chapters that follow, the authors seek to contest far-right claims to Christianity, refusing the path taken by a variant of liberal Christianity, which also relies on essentialist understandings; in this case, the supposed inherence of peace, tolerance, and hospitality in Christianity. Instead, for Strømmen and Schmiedel, we must acknowledge the diversity of historical Christianity, including Christian responsibility for racism and violence, and seek to view Christianity as a project rather than a possession, a 'work in movement'. In this vein, Strømmen and Schmiedel evaluate church responses to far-right claims, criticising, in particular, attempts by church authorities to stay neutral in the battle for the heart of Christianity.

While the content of the chapters is fascinating, Strømmen and Schmiedel spend little time unpacking, connecting, and explaining the constituent ideological parts of the discourses they treat. Such conceptual murkiness is a broader problem within the literature on the rise of the contemporary right, with a proliferation of competing and often unclear designations: populism, right-wing populism, national populism, rightnationalism, new authoritarianism, white nationalism, alt-right, far right, white supremacy, neo-fascism, and so on. Across the various parts of today's right, we see change, convergence, and contradiction, with clear ideological resonances and interactions among groups and overlapping social-media networks and personal bonds in play. ${ }^{12}$ For these and other reasons, and at risk of adding to the terminological cacophony, Traverso's terminology of 'post-fascism' seems to me preferable to the above, capturing a 'phenomenon in transition, a movement that is still in transformation and

12 Nigel Copsey, "Fascism . . but with an Open Mind”: Reflections on the Contemporary Far Right in Western Europe,' Fascism 2, no. 1 (2017): 1-17. 
has not yet crystallized'. ${ }^{13}$ The 'post', then, not only denotes a formation of thought 'still in mutation' following the defeat of $20^{\text {th }}$-century fascist regimes, but also emphasises 'continuity and transformation', instability, and an in-movement quality. ${ }^{14}$ The 'post' rather than 'neo' prefix also resonates with periodising connections to late capitalism and its cultural dominant: post-modernism. ${ }^{15}$ Here, post-fascism is marked by atomised and non-movement qualities, by hyper-textuality, pastiche and irony, by 'a particular regime of historicity', and by ultra-contemporary features of the social mediascape. ${ }^{16}$

We can better visualise Strømmen and Schmiedel's objects of analysis by speaking of a contemporary post-fascist atmosphere: a constellation of ideas, images, structures of feeling, practices, groups, sites, and intellectuals that irradiate influence within and across, for example, right-nationalist parties, white-nationalist groups, alt-right online behaviour, and neoreactionary discourse, and which have seeped into the discourses of some mainstream political parties, media, and popular opinion. Drawing on the emphases of Antonio Gramsci and Ernst Bloch (to which I return in more detail below), and on a variety of other scholarship on the right, I suggest this post-fascist atmosphere is composed of five core features, continuous with classical fascism, but still in formation and movement. ${ }^{17}$

First, post-fascism sets forth a politics centred on an organic, integral, and pure ethnic group, nation, or civilisational bloc. This entails hostility towards outsiders, explicitly or implicitly, which is expressed principally as racism, often of a cultural-civilisational kind: 'the West in Christian hands', for the FPO, for instance. ${ }^{18}$ This appeal to an organic, cohesive, and

13 Traverso, The New Faces of Fascism: Populism and the Far Right (London: Verso, 2019), 6; 'Mutations of Fascism: An Interview with Enzo Traverso,' Verso Blog, 20 December 2017.

14 Traverso, 'Mutations of Fascism'; The New Faces of Fascism, 4.

15 Fredric Jameson, 'Postmodernism, or, the Cultural Logic of Late Capitalism,' New Left Review I/146 (1984): 52-92.

16 Traverso, The New Faces of Fascism, 7.

17 See Chamsy el-Ojeili, 'Keywords: Post-Fascism,' Counterfutures 6 (2018): 101-118.

18 In Brubaker, 'Between Nationalism and Civilizationalism,' 1198. 
pure identity signals a utopian desire around rooted, spiritual, tradition-, morality-, and values-based forms of meaning and belonging, but also, at a societal and political level, to what Camus and Lebourg call 'sovereignism': a politics of strength, decision, and autonomy. ${ }^{19}$ These intertwining utopicidentity and political projects are posited as the means of transcending current conflict, disharmony, and decay, vehicles of what Roger Griffin calls 'palingenesis': redemption through rebirth of group, nation, or civilisation, a rebirth which might overcome present decline, impurity, and betrayal. ${ }^{20}$

Second, this narrative of past, present, and future is often articulated in self-consciously mythic terms, by way of conspiratorial understandings of the present and revisionist understandings of the past. The obverse of post-fascism's utopian espousal of a 'rooted modernity', this involves mobilising a set of dystopian significations and anti-systemic elements, articulated in conspiracy theorising, which is a form of cognitive mapping in which powerful, hidden, and evil forces outside of the true community are seen to control human destinies. ${ }^{21}$ Such conspiricism draws on core tropes of historic anti-Semitism, even when anti-Semitism is formally renounced: opposition to immigration and cosmopolitanism, and to elites in the economic, political, media, and academic spheres; valorisation of 'true producers' and of common sense and ordinary wisdom as opposed to unrooted abstraction and universalism. ${ }^{22}$ The uncovered conspiracy necessitates cleansing the polity of certain ethnic, religious, sexual, or political elements, and begets an obsession with security, safety, and border politics. ${ }^{23}$ This dimension is illustrated well in the rhetoric of war mobilised

19 Jean-Yves Camus and Nicolas Lebourg, Far-Right Politics in Europe (Cambridge: Belknap Press, 2017).

20 Roger Griffin, The Nature of Fascism (London: Routledge, 1991).

21 Griffin, The Nature of Fascism; Michael Barkun, A Culture of Conspiracy:

Apocalyptic Visions in Contemporary America (Berkeley: University of California Press, 2013).

22 Chip Berlet and Matthew Lyons, Right-Wing Populism in America: Too Close for Comfort (New York: Guilford Press, 2000); Enzo Traverso, The Origins of Nazi Violence (New York: New Press, 2003).

23 Ruth Wodak, The Politics of Fear: What Right-Wing Populism Discourses Mean (London: Sage, 2015). 
by Trump and his admirers, around, for instance, building the wall, the threat represented by Antifa and BLM, the attempted Muslim ban.

Third, regarding solutions, this conspiracism, and its cleansing politics, is bound up with charismatic modes of authority, but also with democratic appeals - a thoroughgoing elitism combined with gestures to the people, true representation, popular will, the nation, participation, and community. ${ }^{24}$ Dylan Riley aptly frames this characteristic as 'authoritarian democracy'. ${ }^{25}$ Thus, Steve Bannon both appeals to the people at large, naming his sovereignist project 'The Movement', while simultaneously espousing the Traditionalist School's emphasis on the restoration of hierarchy and the role of a heroic (male) spiritual elite. ${ }^{26}$

Fourth, while post-fascism should not be seen as merely a set of negations or a simulacrum of revolution, it cannot be understood in the absence of counter-revolutionary or backlash politics. ${ }^{27}$ It draws from, and fervently, obsessively reacts against, left political and cultural forms and figures: sometimes, say, appropriating dimensions of socialism, but also drawing 'ideological and organisational energy' in attacking left organisations and values. Thus, a sector of today's post-fascism imagines itself as a 'new counter-culture' or 'new punk', drawing upon a Gramscianinflected meta-politics to oppose the values of the 'generation of ' 68 ', particularly the egalitarianism of the new left. ${ }^{28}$

Finally, both military and gendered-bodily dimensions are central to

24 Umberto Eco, 'Ur-fascism,' New York Review of Books, 22 June 1995; Ishay Landa, The Apprentice's Sorcerer: Liberal Tradition and Fascism (Leiden: Brill, 2014); Darko Suvin, 'To Explain Fascism Today,' Critique 45, no. 3 (2017): 259-302.

25 Dylan Riley, The Civic Foundations of Fascism in Europe (London: Verso, 2010).

26 Joan Braune, 'The Outsider as Insider: Steve Bannon, Fourth Turnings, and the Neofascist Threat,' in Spectres of Fascism: Historical, Theoretical and International Perspectives, ed. Samir Gandesha (London: Pluto Press, 2020).

27 Robert Paxton, The Anatomy of Fascism (New York: Alfred A. Knopf, 2004); Riley, The Civic Foundations of Fascism; Traverso, The Origins of Nazi Violence. 28 Angela Nagle, Kill All Normies: Online Culture Wars From 4chan to Tumblr to Trump and the Alt-Right (Winchester: Zero Books, 2017); Mike Wendling, Alt-Right: From 4chan to the White House (London: Pluto Press, 2018); Tamir Bar-On, 'Richard B Spencer and the Alt-Right,' in Key Thinkers of the Radical Right: Behind the New Threat to Liberal Democracy, ed. Mark Sedgwick (Oxford: Oxford University Press, 2019). 
post-fascism, coinciding with what we now describe as 'toxic masculinity'. Crucial is the exaltation of battle and martial values: struggle, violence, strength, loyalty, courage, youth, virility, decision, and a disdain for women. Today, this is found, among other places, in oppositions to feminism, 'gender ideology', and political correctness in the 'Crusader Christianity' Strømmen and Schmiedel point to, a 'return' to the warlike, sacral, 'muscular' Christianity of the Middle Ages, against contemporary religious pacifism, egalitarianism, and tolerance. ${ }^{29}$

Just as fascism grew out of what Zeev Sternhell calls 'a general condition of distress', ${ }^{30}$ today's post-fascist atmosphere, its 'nebula of attitudes', 'emotional lava', and 'mobilising passions', ${ }^{31}$ gathers by way of what Marco Revelli describes as a 'diffuse feeling of rage, unease and suspicion', a sense many people have of being 'divested of something'; of 'their male privilege, part of their (however high) income, their societal status, recognition of their work, respect for their faith or their country, their place in the world, their power, their hegemony'. ${ }^{32}$ This atmosphere, an intellectual formation in formation, is, like any ideology, but in extremis, a 'panorama of discrepancies', a 'highly unstable, non-homogenous composite' made up of many layers, including Christian, non-Christian, and anti-Christian deposits. Increasingly, however, Christian significations play an important organising role within this atmosphere. ${ }^{33}$

\section{Instrumentalisation?}

In responding to far-right claims to Christianity, Strømmen and Schmiedel's

29 Strømmen and Schmiedel, The Claim to Christianity.

30 Zeev Sternhell, Neither Right nor Left: Fascist Ideology in France (New Jersey: Princeton, 1986), 271.

31 Paxton, The Anatomy of Fascism, 40-41.

32 Marco Revelli, The New Populism: Democracy Stares into the Abyss (London: Verso, 2019), 202, 72-73.

33 Paolo Favilli, The History of Italian Marxism: From its Origins to the Great War (Leiden: Brill, 2016), 13, vii. 
insistence that we are not dealing with a mere instrumentalisation of Christian belief - the cynical, simply rhetorical use of Christian ideas and symbols for the purpose of gaining power-is salutary. On this issue, the authors find the dominant liberal-Christian response, the story of a good, authentic, liberal Christianity set against a bad, hijacked, farright Christianity, 'too nice and too neat to convince'. ${ }^{34}$ Strømmen and Schmiedel's stance here opposes not only the positions occupied by many mainline churches, but also, implicitly, an older line of interpretation of historic fascists' manipulation of religious belief for their own ends. I explore these questions in this section, suggesting that the connections between fascism/post-fascism and Christianity exceed mere instrumentalisation.

Strømmen and Schmiedel underscore the galvanising role of Islamophobia for the far right and the shift from biological to cultural or civilisational racism, where religion, viewed as static and basic, comes every bit as much as biology to function as immutable nature, justifying discrimination, exclusion, and inequality. Rather than cynically instrumentalising Christianity, post-fascist conceptions of the world are frequently rooted in a civilisational framework, in which the authentic descendants of the Christian West are viewed as quite separate from, and at least implicitly superior to, those of the Muslim East.

Two intriguing aspects of this are raised by Strømmen and Schmiedel, although neither is elaborated upon. First, in line with the complicated postfascist borrowing from and rejection of the left, we see Culture Christianity developing contentions that echo the progressive identity-politics ethos of 'the right to difference', a question to which I turn in the following section. Second, we often find an elision within this Culture Christianity between a defence of 'Christian' or 'Judeo-Christian' culture and a defence of Western secularism and liberalism, an apparent appeal to the faithful and faithless all at once. This elision is exemplified by Marine Le Pen, whose party's mascot is Joan of Arc, who often wears a prominent crucifix, and who has spoken

34 Strømmen and Schmiedel, The Claim to Christianity, 138. 
of her 'deep faith'. ${ }^{35}$ Le Pen underscores, all at once, France's 'Christian roots' and the connection between these roots and secular values: 'The principles we fight for are engraved in our national motto: liberty, equality, fraternity', which 'stems from the principles of secularization resulting from a Christian heritage'. ${ }^{36}$ An equivalent alignment is suggested by Geert Wilders in the Netherlands, between Christianity, Judaism, and humanism, and by PEGIDA's use of crosses as symbols of 'Western values' ${ }^{37}$ In similar fashion, cheek-by-jowl with dozens of explicit references to Biblical texts, in his manifesto Breivik conceded that he was not an 'excessively religious man', positing Christianity 'as a cultural, social, identity and moral platform'. ${ }^{38}$

Explicating such sentiments and elisions, Brubaker contends that the increasing salience of Christian identity on the far right is linked with a move in a more civilisational direction and a Christianity as culture (belonging)—what he calls 'Christianism'—rather than Christianity as substantive religion (worship). ${ }^{39}$ For Brubaker, this is identity purely by negation; it is reactive and thoroughly conditioned by the preoccupation with Islam. This reading is bolstered by evidence that suggests that practising Christians, outside of Eastern Europe, have tended to remain immune to the message of the 'national-populist' parties, the AfD for example, scoring twice as high with non-religious as with religious voters, and neither FN nor Lega performing terribly well with churchgoers. ${ }^{40}$

There are, of course, grounds to be sceptical about the depth of religious conviction espoused by post-fascists. Such a sceptical, instrumentalist interpretation aligns with the 'political religions' reading

35 Karina Piser, 'In Secular France, Catholic Roots Run Deep,' Institute of Current World Affairs, 29 April 2019.

36 In Emma Green, 'The Spectre of Catholic Identity in Secular France,' The Atlantic, 6 May 2017.

37 Piser, 'In Secular France'; Matthew Bell, 'Never Mind the Cross, Germany's “Anti-Islamization” Movement Isn't Really Christian,' The World, 12 February 2015.

38 In Hannah Strømmen, 'Christian Terror in Europe? The Bible in Anders Behring Breivik's Manifesto,' Journal of the Bible and its Reception 4, no. 1 (2017): 153.

39 Brubaker, 'Between Nationalism and Civilizationalism.'

40 Kathleen Montgomery and Ryan Winter, 'Explaining the Religion Gap in Support for Radical Right Parties in Europe,' Politics and Religion 8 (2015): 379-403. 
of classical fascism, which emphasises its function as religion, in place of Christianity. The pioneering work of George Mosse on Nazism and Emilio Gentile on Italian fascism implied a dissociation and relativisation of the fascism-Christianity connection. ${ }^{41}$ Here, fascism is understood as an intended substitute worldview to Christianity, loaded with Christian imagery and themes — end times, overcoming evil (the 'triumphant beast' ${ }^{42}$ of Bolshevism), apostleship, blood, martyrdom, saviours-but, in essence, a civic, patriotic, secular religion, which sought to 'nationalise the masses ${ }^{3 / 3}$ and used traditional religion 'as a way of smoothing its search for power. ${ }^{44}$ For Gentile, the relationship between fascism and the Catholic Church was one of rivalry for the 'formation and control of the Italian conscience', a 'war of symbols', the deeper content of fascism being anticlerical, iconoclastic, and paganising, and fascism's 'Christianity' is read as part of a wider story of the sacralisation of politics in the modern age. ${ }^{45}$ In a similar way, Mosse accents the occult origins of Nazism, and the Nazis' attempts to use and bend Christianity into conformity with their own discrepant ideology and culture. ${ }^{46}$

Against this political-religious line of argument, many leading Nazis did indeed view themselves and their movement as Christian: Hitler declaring that 'by defending myself against the Jew, I am fighting for the work of

41 George Mosse, Nazi Culture: Intellectual, Cultural and Social Life in the Third Reich (London: WH Allen, 1966); The Fascist Revolution: Toward a General Theory of Fascism (New York: Howard Fertig, 2000); Emilio Gentile, The Sacralization of Politics in Fascist Italy (Cambridge: Harvard University Press, 1996); The Origins of Fascist Ideology, 1918-1925 (New York: Enigma, 2005). These readings set to one side a range of 'clerical fascisms': Codreanu's Legion of the Archangel Michael in Romania, the Arrow Cross in Hungary, the Rexist Party in Belgium, the Falange Espanola.

42 Gentile, The Sacralization of Politics, 54.

43 Mosse, The Fascist Revolution, 50.

44 Gentile, The Sacralization of Politics, 53.

45 Gentile, The Sacralization of Politics, 69. Consistent with lifelong atheist, Mussolini, whose secret report of 1930 read: 'There is no need to get all tied up with antireligiousness and give Catholics reason for unease. ... A fight on this ground between Church and State, the State would lose. . . On the other hand, when they try to interfere in politics, socially, in sport, then we fight them': in Gentile, The Sacralization of Politics, 70.

46 Mosse, Nazi Culture; The Fascist Revolution. 
the Lord'; Goebbels claiming that 'The struggle we are now waging today until victory or the bitter end is, in its deepest sense, a struggle between Christ and Marx’. ${ }^{47}$ For Richard Steigmann-Gall, Christian themes and tendencies within Nazism cannot be explained in terms of opportunism or tactical restraint, and far too much has been made of the paganising tendencies within the Nazi party, which were there, but never dominated nor got the recognition its intellectuals yearned for. Further, even the paganising Nazis continued to draw on Christianity, and, in later years, as antagonisms with the institutions of the Church grew, Nazi attitudes were shot through with contradiction and ambiguity. In sum, Christianity was not a barrier to fascism; rather, Nazism 'was infused with key elements of Christian belief'. ${ }^{48}$

Given the continuing availability and power of religious themes as a resource in the search for identity, the more complex relationship between historical fascism and Christianity suggested by other scholars, and the impossibility of discerning the substantiality of belief in any case, Strømmen and Schmiedel's refusal of an instrumentalist reading, and their insistence on acknowledging historic Christianity's entanglement with racism and violence, seem better options. It is probably more productive to reflect upon the force of the appeal to Christianity, the magic by which it works, and the ways in which it jostles or meshes with disparate elements within post-fascism. Here, an understanding of post-fascism's ideological and utopian machinery, and the functions of its Christian cogs, requires further theoretical mediation.

\section{A 'powerful cultural synthesis'}

I want to add, then, to the conceptualisation I have suggested above in my ideal-typical treatment of post-fascism, developing further emphases from the work of Bloch and Gramsci around questions of utopia and ideology,

47 In Richard Steigmann-Gall, The Holy Reich: Nazi Conceptions of Christianity, 1919-1945 (Cambridge: Cambridge University Press, 2003), 36, 13.

48 Steigmann-Gall, The Holy Reich, 265. 
synthesis and stratification, to suggest ways of filling in spaces left blank by Strømmen and Schmiedel. In particular, Bloch and Gramsci draw our attention to imagery of a better way of being (personal and collective transformation), to the combination of various elements that mobilise the passions, and to claims to identity and belonging, all of which do crucial work in organising popular will and establishing a civil bond between leaders and 'the people'.

In his 1935 work, The Heritage of Our Times, Bloch explores fascism's utopian dimensions, depicting fascism as a 'powerful cultural synthesis', which expresses authentic longings for something different in the face of disenchantment, immiseration, and fears of decline. ${ }^{49}$ This synthesis, comprising 'new figures' and 'hybrid structures', included elements of 'earlier forces' (fairy-tale, myth, Romanticism, occultism, and magic), appropriations from the contemporary left (the languages of the street, revolution, and participation), the appeal to 'masculine qualities' (strength, openness, and purity), and tropes from vitalist philosophy (will, life, creation, archaic surging, and instinctive knowledge). ${ }^{50}$ It also included elements of Christianity. Here, Bloch points to the Nazi localisation of Christianity, where 'God becomes the Prime Minister of Germany, German birth a Christian baptism, ritual murder of Jews a Sermon on the Mount, unparalleled natural magic a descent of the Holy Ghost. Murder calls itself the SA of Christ'. ${ }^{51}$ And Biblical themes, says Bloch, are core to the Nazi notion of the thousand-year Reich, with roots in Isaiah 30, 55, and 60, Book of Daniel 7, and Revelation 20 and 21, dealing with the final battle of historical time and the abundant life of the age to come.

In Gramsci, we find aligned emphases in a constellation of concepts used to explore ideological composites and stratification. Gramsci shared with Bloch a keen interest in Christianity, an emphasis on historical affinities between early Christianity, Christian heresies, and socialism,

49 In Anson Rabinbach, 'Unclaimed Heritage: Ernst Bloch's Heritage of Our Times and the Theory of Fascism', New German Critique 11 (1977), 5.

50 Bloch, The Heritage of Our Times, 3; 'Nonsynchronism and the Obligation to its Dialectics,' New German Critique 11 (1977): 32, 22.

51 Bloch, The Heritage of Our Times, 95. 
and an insistence that Marxism required a faith-based dimension, framed by Gramsci in explicitly religious terms, as intellectual and moral reformation'.52 In line with Strømmen and Schmiedel's historical and anti-essentialist emphases, Gramsci saw Christianity as 'a multiplicity of distinct and often contradictory religions'.53 Despite this multiplicity, historical Christianity shared certain features with the philosophy of praxis (Marxism), seeking to provide a 'single and coherent conception of the world' which could lead people to 'a higher conception of life', elaborated by intellectuals, and striving for doctrinal unity and an organic connection between intellectual and popular strata. ${ }^{54}$

For Gramsci, however, Christianity's organicity had declined significantly since the Counter-Reformation, a decline deepened after 1848 by the ascendance of liberalism, with Christianity increasingly combining, in disintegrative ways, with other ideological strands. ${ }^{55}$ Aside from religion, philosophy, and science, common sense is the most well-known of these strands, which Gramsci often characterises in negative terms as 'fragmentary, incoherent and inconsequential', 'crudely neophobe and conservative', containing a strata of reactionary and fossilised 'sediments' ${ }^{56}$ For Gramsci, while common sense also contained portions of 'good sense' opposed to official conceptions of the world, also present were the most superstitious, acritical, and crudely materialistic notions drawn from a decomposing Christianity. As well as fragments of science and philosophy, folkloric elements are another presence within common sense. Including superstitions, magic, spirits, witchcraft, popular morality, proverbs, fables, certain motifs (say, the noble hero), regional and local literature and

52 Antonio Gramsci, The Antonio Gramsci Reader, ed. David Forgacs (London: Lawrence and Wishart, 2000), 350.

53 Gramsci, Selections from the Prison Notebooks, 420.

54 Gramsci, Antonio Gramsci Reader, 334, 333; Selections from the Prison Notebooks, 328,361 .

55 Walter Adamson, 'Gramsci, Catholicism and Secular Religion,' Politics, Religion and Ideology 14, no. 4 (2013): 468-484; Marcus Green, 'Gramsci's Concept of the "Simple": Religion, Common Sense, and the Philosophy of Praxis,' Rethinking Marxism 30, no. 4 (2018): 525-545.

56 Gramsci, Selections from the Prison Notebooks, 419, 423; Antonio Gramsci Reader, 364. 
songs, folklore is framed by Gramsci as connected to traditional authority, dismissed ideas, fossilised forms of knowledge, and, crucially, provincial or parochial cultural expressions. ${ }^{57}$ Nevertheless, folklore contains elements in opposition to official (liberal) conceptions of the world: it is multiple, with different groups having different folkloric conceptions, and it is still 'a reflection of the conditions of life of the people, although folklore frequently persists even after these conditions have been modified in bizarre combinations'..$^{58}$

Bloch's and Gramsci's attention to the utopian, dystopian, oppositional, stratified, temporally multiple, and synthetic quality of political thought provides us with means of enriching our understanding of the workings of the Christian-post-fascism connection that Strømmen and Schmiedel seek to illuminate. The contemporary post-fascist atmosphere contains a multifarious mix of philosophical, scientific, common-sensical, and folkloric elements, and the Crusader and Culture Christianities Strømmen and Schmiedel outline have a crucial function, I suggest, as a central concrete fantasy that might organise this disparate material into a form of 'total social practice'. ${ }^{59}$ This provides us with an additional vantage point to the predominant commentary, which has focused on the fear-filled and nihilistic quality of what I am treating as post-fascism. Wendy Brown, for example, emphasises modern disenchantment and the diminishment of values, chronically exacerbated by neoliberalism, financialisation, and digitisation, which has culminated in 'new quantities and subjects of ressentiment, and a nihilism beyond Nietzsche's vivid dreams' ${ }^{60}$ For Brown, interminable far-right trolling, its pleasure in provoking, humiliating, and making others suffer, signals pure negation, the complete absence of any values, of any hopes for, or attempts at, world-shaping, and is animated by a desublimated will to power, 'ethical destitution', revenge and rancour,

57 Stephen Gencarella, 'Gramsci, Good Sense, and Critical Folklore Studies,' Journal of Folklore Research 47, no. 3 (2010): 221-252.

58 Gramsci, Prison Notebooks, vol. I (New York: Columbia University Press, 2011), 187.

59 Frosini in Zene, 'Subalterns in the World,' 122.

60 Wendy Brown, In the Ruins of Neoliberalism: The Rise of Antidemocratic Politics in the West (New York: Columbia University Press, 2019). 
and death drive. ${ }^{61}$ For Bloch, though, the utopian elements of classical fascism were 'signs of flight from relativism and nihilism'; we could posit that Christian significations play a correlative role in re-enchantment, the affirmation of a horizon of values, and the appeal to foundations, providing an ideological and emotional glue for the contemporary postfascist atmosphere. ${ }^{62}$ How so? The answer, I think, lies in the connections between Christianity and conspiracism, masculinity, and folklore.

I have already noted post-fascist borrowings from the philosophical vocabulary of liberalism-for instance, free speech, individual freedom over equality, opposition to leftist social engineering. Elements of socialist philosophy and anti-systemic good sense, from opposition to centrist political parties, corporate and intellectual elites, globalist (neo)liberalism, right up to challenges to global capitalism and its materialist culture, are equally characteristic features of the post-fascist imaginary. But these elements of anti-systemic good sense are bound to emotionally charged dystopian and conspiracist figures. Two central conspiracist notions within post-fascism provide some insight into the ways this potentially intertwines with apocalyptic Christian appeals. First, Bat Ye'Or's Eurabia conspiracy (a plot to establish Muslim control of Europe), mentioned 171 times in Breivik's manifesto, and related counter-jihadist ideas are noted by Strømmen and Schmiedel. However, they fail to link them clearly to post-fascist Christian-identity claims, historical anti-Semitism, and attempts to cognitively map the world and power; nor do they take up the connections between this and a second major conspiracist notion, that of 'cultural Marxism'. Arguably connected to the classical fascist notion of 'cultural Bolshevism', which was also taken up by certain churches in the interwar period, the aims of cultural Marxism, according to the neoNazi Stormfront website, include 'Huge immigration to destroy identity

61 Brown, In the Ruins of Neoliberalism, 171.

62 Bloch, 'Nonsynchronism,' 26. 
... [the] [e]mptying of churches'. ${ }^{63}$ This theory is now widely available, deployed in mainstream media by political parties (UKIP, for instance, but also the Conservative party), and the likes of Jordan Peterson.

In a similar vein - and, again, this remains not only untreated in Strømmen and Schmiedel, but unmentioned-Crusader Christianity is intertwined with a series of temporally disparate appeals to a re-rooted masculinity, founded, at times, on a folkloric science ('sex realism'), in opposition to gender ideology/gender research, 'leftist LGBT forces', 'toxic femininity', and egalitarianism, all of which attack 'true manhood'. ${ }^{64}$ In Breivik's manifesto, the selection of martial Bible passages is combined with arguments for the jettisoning of pacifist, egalitarian, and genderneutral translations of scripture. ${ }^{65}$ The 'much more muscular' Christianity to which Nigel Farage appeals is a Christianity brimming with masculine qualities of decision, strength, will, struggle, and dynamism. It coincides with a contemporary variant on the 'new man' anthropology of classical fascism, and is often bound to ultra-contemporary masculinities associated with gym culture or mixed martial arts, but also to virtual-gaming battle imaginaries centred upon fantasy, special forces, sci-fi, and post-apocalyptic genres. ${ }^{66} \mathrm{~A}$ muscular Christianity is a significant feature of the US religious landscape, captured, for example, in Father Larry's 2009 book Be A Man: 'Jesus Christ was a man's man. He gave everything to prove that - just look at a crucifix! ${ }^{67}$

Folkloric notions are also at work at the utopic and identity level in post-fascist appeals to parochial origins and stories and symbols of belonging, invocations of the magical power of charismatic leadership or

63 Andrew Woods, 'Cultural Marxism and the Cathedral: Two Alt-Right Perspectives on Critical Theory,' in Critical Theory and the Humanities in the Age of the Alt-Right, eds. Christine Battista and Melissa Sande (London: Palgrave, 2019). On cultural Bolshevism, see Paul Hanebrink, A Spectre Haunting Europe: The Myth of Judeo-Bolshevism (Cambridge: Belknap Press, 2018).

64 Dominic Wetzel, 'The Rise of the Catholic Alt-Right,' Labor and Society 23 (2020): 35.

65 Strømmen and Schmiedel, The Claim to Christianity.

66 Strømmen and Schmiedel, The Claim to Christianity, 101.

67 Wetzel, 'The Rise of the Catholic Alt-Right,' 44. 
collective will, mythic tropes of male bonding and heroism, and pagan and occult influences. Of the last, the symbolism and language of a postfascist Crusader Christianity — say, the Cross of Saint George, the Knights Templar, Pope Urban II, 'Defend Europe . . . Deus Vult' (God Wills It)_ jostles alongside imagery drawn from Greek and Roman antiquity, or from the Norse past: Sparta, the battle of Thermopylae, the Parthenon, SPQR, the Roman military eagle, Vikings, Odinism. ${ }^{68}$

This imaginary of battle and struggle, pitched in an apocalyptic register, energises a passion for post-fascist trolling, understood in terms again borrowed from leftist discourse as consciousness raising and metapolitical struggle, glossed by Guillaume Faye as the 'social diffusion of ideas and cultural values for the sake of provoking profound, long-term, political transformation'. ${ }^{69}$ In 'dominionism', a specifically Christian variant of such meta-politics, Christians are to seek domination over crucial cultural and political 'kingdoms': government, law, education, science, business, media, arts, entertainment, and family. ${ }^{70}$ Such meta-political struggle, as a corollary of conspiracist cognitive mapping, expresses an apocalyptic post-fascist desire to cleanse the social order by, variously, reconfiguring education, as in Breivik's call for a sociology purged of Marxism and centred on the Bible as central textbook; ${ }^{71}$ creating alternative media institutions to that of the secularist and globalist 'media monopoly'; ${ }^{72}$ policing foreign elements through stronger borders, tighter citizenship criteria, and deportation of outsiders; attacking institutionalised privileges for immigrants or minorities; proscribing Islamic symbols, rituals, or attire; and re-elevating 'ChristianOccidental values'. All of these cleansing, securitising elements are shot through with both utopian desires for a better way of being (a pure, rooted identity, an integral, unpolluted, transparent community), and dystopian

68 Zuquete, The Identitarians.

69 In Benjamin Teitelbaum, 'Daniel Friberg and Metapolitics in Action,' in Thinkers of the Radical Right: Behind the New Threat to Liberal Democracy, ed. Mark Sedgwick (Oxford: Oxford University Press, 2019), 2.

70 Wetzel, 'The Rise of the Catholic Alt-Right.'

71 Strømmen, 'Christian Terror in Europe?'

72 Jobbik, 'Manifesto': http://www.jobbik.com/manifesto_0 
fears about catastrophe, insecurity, and decline.

In paying attention to the utopian, dystopian, ideologically layered, and synthetic dimensions of an increasingly Christianised post-fascism, we glimpse how Strømmen and Schmiedel's analysis can be enriched. In particular, we get a sense of how Christianity might play a distinctive, organising function across a dispersed post-fascism, a presently unelaborated, unsystematised 'museum of fragments' (as Gramsci described folklore). ${ }^{73}$ Offering an extant set of beliefs, practices, and organisational structures, Christianity seems increasingly to bind many of post-fascism's elements in a more organic fashion and provide moral and spiritual energy, the consequence of which might be a shift from today's more nebulous atmosphere to more sedimented post-fascist movements, parties, and institutions. How, then, to fight post-fascist Christianity?

\section{Another Christianity is possible!}

The under-theorised, unelaborated quality of Strømmen and Schmiedel's treatment of these questions is undoubtedly an expression of the activist, militant purposes of the authors (with Christianity conceived of as a practical, quotidian, and ongoing project); indeed, a good part of the text is dedicated to exploring Christian responses to post-fascism. In each of the substantive chapters, Strømmen and Schmiedel weigh mainline church reactions to the present synthesis of post-fascism and Christianity, falling into one of two categories. The first, the 'consolidating Church', found in the German Protestant Church and the Church of England, takes a middle road, and is judged as complicit or at best complacent. These churches have framed their contribution as providing a neutral space, free from both farleft and far-right extremism, and as playing a role in sustaining democracy. The latter is to be achieved either by encouraging more consensus or more contestation: a 'corridor', in German Protestantism; a gentle, evenhanded critique of both left and right extremism and stereotyping among

73 Gramsci, Prison Notebooks, 186. 
Church of England bishops; a Christian-supremacist welcoming of lawcentred Islam on grace-centred Christian terms, for Archbishop Welby. Such approaches carry the implicit assumption that Christians are always already democratic, tolerant, and respectful of human rights, particularly in contrast to Muslims.

The second and preferred option, glimpsed in the Church of Norway's reaction to Breivik's murders, is the 'challenging church'. Strømmen and Schmiedel reject neutrality, which, they insist, is itself a political position, in favour of liberation theology's preferential option for the poor, with poverty understood expansively to include marginalisation, demonisation, and discrimination - in short, any ideas or practices that turn a person into a non-person. Here, a more deliberative democratic stance is visible: citizen involvement, the need for Christians to be forthright, to 'stay and sink their teeth in' ${ }^{74}$ Significantly, this entails self-criticism and responsibility, a recognition that 'There is not just one Bible', that the 'history of Christianity has been shaped by hatred', and an acknowledgement of Christianity's historical complicity with racism and Islamophobia. ${ }^{75}$ Above all, this is a Gramscian Christianity without guarantees, a recognition that struggle is all there is, that Christianity is a project rather than a possession, that it cannot be owned, that it is 'neither fixed nor finished'. ${ }^{76}$ We need to continually figure out what it means to be Christian in practice, how to 'Go and do likewise' (Luke 10:37), 'in conversation, collaboration and contact with Muslims' and others. ${ }^{77}$

This is undoubtedly a compelling rejoinder to liberal Christianity, and, however implicit, a good Gramscian reminder of the priority of an ongoing struggle for intellectual and moral reformation. Here, a more expansive conceptualisation of the contemporary right, of post-fascism's powerful cultural synthesis, including its religious musicality, helps us to extract the authentic longings for something different that are present within this

74 Strømmen and Schmiedel, The Claim to Christianity, 129.

75 Strømmen and Schmiedel, The Claim to Christianity, 135, 129.

76 Strømmen and Schmiedel, The Claim to Christianity, 137.

77 Strømmen and Schmiedel, The Claim to Christianity, 145. 
atmosphere, to better understand the magic by which it works for certain strata, and, perhaps, to imagine compelling ways in which a powerful alternative theology might be developed. Such a theology entails, all at once, rational, emotional and spiritual valences. As Hollis Phelps has noted, the left requires its own versions of 'visceral' politics, a politics currently available within post-fascism. ${ }^{78}$ On this score, both Bloch and Gramsci appealed to the positive religious qualities of Marxism and socialism, and underscored the connection between early Christianity, heretical Christian movements, and socialism. ${ }^{79}$ There is surely plenty to be ashamed of in Christian history, but also much that can inspire the contemporary left: Christian challenges to systems of domination; the search to transform self (metanoia) and world (on earth as in heaven); 'all things in common' (Acts 2: 44); open commensality, free healing, and unconditional welcoming; faith as loyalty, trust, and hope. ${ }^{80}$ Fighting for this other history and practice, for lost Christianities, is an important but often neglected or dismissed dimension of left politics. In the face of the dangerous ideological creations emergent in today's post-fascist atmosphere, this is a struggle of particular urgency.

78 Hollis Phelps, 'Qanon,' The Magnificast Podcast, 18 September 2020.

79 Roland Boer, Criticism of Heaven: On Marxism and Theology (Leiden: Brill, 2007).

80 John Crossan, The Birth of Christianity: Discovering What Happened in the Years Immediately After the Execution of Jesus (San Francisco: Harper, 1998). 